\title{
Pengaruh Penggunaan Deltametrin Pada Buah Kakao (Theobroma cacao L.) terhadap Kualitas Tanah
}

\author{
Maretik \\ Universitas Sembilanbelas November Kolaka \\ e-mail: maretik237@gmail.com
}

\begin{abstract}
Abstrak
Tanaman kakao saat ini mengalami penurunan produksi karena serangan hama penggerek buah kakao. Upaya pengendalian hama PBK biasanya menggunakan pestisida kimiawi sintetik jenis deltametrin. Namun, pemberian pestisida ini secara terus menerus dikhawatirkan akan berpengaruh buruk terhadap kualitas tanah. Tujuan dari penelitian ini adalah mengkaji pengaruh penggunaan deltametrin terhadap kualitas tanah. Penelitian ini menggunakan deltametrin dengan konsentrasi 0 ppm (kontrol) dan 25 ppm dengan 5 ulangan. Parameter kualitas tanah meliputi fisika tanah (bulk density, porositas tanah), kimia (bahan organik, $C, N, P$ ) dan biologi tanah (kelimpahan serangga tanah). Hasil yang diperoleh pada fisika tanah (porositas tanah dan bobot isi) tidak berbeda nyata antara perlakuan dan kontrol (37,80\% dan 36,74\% ; 1,65 g/cm3 dan 1,68 g/cm3; P<0,005). Pada biologi tanah (kelimpahan fauna tanah) ada perbedaan antara perlakuan dan kontrol (32 ekor dan 69 ekor). Pada kimia tanah (Bahan organik, $C, N, P$ dan K) terdapat perbedaan antara perlakuan dan kontrol $(1,64 \%$ dan $2,17 \% ; 0,95 \%$ dan $1,26 \% ; 0,009 \%$ dan 0,11\%;0,009\% \& 0,014\% ; 0,001\% \& 0,005\% ; P<0,005). Hasil ini menunjukkan bahwa pemberian deltametrin pada tanaman kakao tidak berpengaruh terhadap sifat fisik tanah, akan tetapi berpengaruh terhadap biologi tanah yaitu terhadap kelimpahan fauna tanah, dan mempengaruhi kimia tanah.
\end{abstract}

Kata kunci : Deltametrin, Kualitas Tanah, Theobroma cacao L.

\section{PENDAHULUAN}

Tanaman kakao (Theobroma cacao L.) merupakan salah satu tanaman perkebunan yang memiliki nilai ekonomis sangat baik karena peluang pasarnya sangat besar. Menurut Syafira dkk., (2012) kakao dapat digunakan sebagai bahan makanan dan berperan penting dalam dunia kesehatan karena mengandung senyawa theobromin yang berfungsi dalam pengobatan penyakit. Beberapa fungsi theobromin yaitu sebagai anti kanker, diuretic, stimulant kardiak, hypocholesterolemic, smooth-muscle relaxants, vasodilatos asma dan koroner (Bispo, 2002; Hartati, 2012).

Sulawesi Tenggara merupakan salah satu provinsi penghasil kakao terbesar di Indonesia dengan daerah penghasil kakao terbesar adalah Kolaka. Sebagai komoditas andalan Kolaka, kakao sangat berperan penting dalam status perekonomian di Sulawesi tenggara. Namun, saat ini produksi kakao di Sulawesi Tenggara mulai terancam dengan adanya serangan hama penggerek buah kakao (PBK), yang disebabkan oleh serangga Conopomorpha cramerella Snell. Hama ini dapat menimbulkan kehilangan hasil hingga 90\% (Sulistyowati dkk., 2006).

Salah satu upaya pengendalian hama PBK yang telah dilakukan untuk menekan pertumbuhannya adalah penggunaan pestisida kimiawi sintetik dari golongan pyretroid yang meliputi deltametrin, sipermetrin, alfasipermetrin, sihalotrin, fipronopil, esfenfalerat dan betasiflutrin dengan konsentrasi 0,006-0,12\% (Sulistyowati, 2008). Di antara pestisida-pestisida tersebut, deltametrin memiliki kemampuan mengendalikan serangan PBK yang paling tinggi mencapai 94,7\% (Wahyudi dkk., 2008).

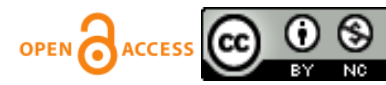


Pemberian deltametrin secara terus menerus pada tanaman kakao dikhawatirkan akan berpengaruh buruk terhadap mikroba tanah yang berperan sebagai organisme pendekomposer yang mengurai serasah. Penurunan kelimpahan organisme tanah akibat penggunaan deltametrin telah dilaporkan oleh Purwanta (1998) dan dikhawatirkan akan mempengaruhi ketersediaan nutrisi tanah akibat menurunnya laju dekomposisi serasah oleh organisme pendekomposer. Oleh karena itu, perlu dilakukan penelitian untuk menjelaskan pengaruh penggunaan pestisida deltametrin terhadap kualitas tanah pada kebun kakao.

Tujuan penelitian ini adalah mengkaji pengaruh penggunaan deltametrin terhadap kualitas tanah (sifat fisik, sifat kimia dan sifat biologi), dan mengkaji hubungan antara kandungan nutrisi tanah dan kandungan nutrisi buah kakao.

\section{METODE PENELITIAN}

Penelitian ini berlangsung dari bulan Juni 2014-Juli 2015 dan dilaksanakan di kebun kakao milik petani di Kelurahan Ranomentaa Kecamatan Toari Kabupaten Kolaka. Analisis sampel dilakukan di Laboratorium Perkembangan Tumbuhan SITH ITB dan BPTS Lembang, Jawa Barat. Tanaman kakao yang digunakan sebagai sampel berumur sekitar 3-4 tahun. Penentuan sampel dilakukan dengan memilih pohon dengan umur yang sama secara acak. Sebanyak 10 tanaman, kakao kemudian dibagi menjadi 2 kelompok yaitu kelompok kontrol dan perlakuan masing-masing dengan jumlah 5 pohon.

Pengaruh pestisida terhadap kandungan nutrisi tanah diamati dengan menyemprotkan pestisida deltametrin pada konsentrasi 25 ppm menggunakan alat penyemprotan knapsack sprayer pada pohon. Penyemprotan dilakukan sebanyak lima kali dengan interval waktu 10 hari (Prawoto dkk., 2008). Penyemprotan diarahkan pada batang yang memiliki buah kakao dan pada cabang-cabang horizontal. Indikator penilaian kualitas tanah pada penelitian ini terdiri dari sifat fisik tanah (bobot isi tanah, porositas, tekstur tanah, kadar air tanah), sifat biologi tanah (kelimpahan dan keragaman populasi fauna tanah), dan sifat kimia tanah (Bahan organik, C, N, P, K, pH).

Pada pengamatan biologi tanah dilakukan pencuplikan serangga tanah, yang dilakukan dengan menggunakan perangkap sumur (pitfall trap) terbuat dari gelas plastik berdiameter $5 \mathrm{~cm}$ dan tinggi $10 \mathrm{~cm}$. Pemasangan perangkap dilakukan dengan menanamkan gelas tersebut dipermukaan tanah. Gelas diisi alkohol $70 \%$ dan setetes gliserin untuk mengurangi penguapan alkohol. Permukaan gelas disimpan sejajar dengan permukaan tanah dan diletakkan di daerah yang relatif kering agar air tidak masuk. Gelas yang telah dibenamkan diberi penutup agar tidak ada kotoran dari atas yang masuk kedalam gelas. Pemasangan perangkap dilakukan mulai hari pertama penyemprotan dan diletakkan disekitar pohon kakao secara acak. Hasil perangkap tersebut dimasukkan kedalam tabung plastik dan ditutup untuk dianalisis jenis serangganya.

Pengambilan sampel untuk analisis sifat fisik tanah (porositas, bulk density, kadar air tanah, tekstur tanah) dilakukan dengan menggunakan ring sample yang diletakkan pada 3 titik di sekitar sampel pohon. Sampel tanah untuk analisis sifat kimia tanah (bahan organik, kandungan N, C, P, K dan pH tanah) dilakukan dengan mengambil tanah masing-masing $250 \mathrm{~g}$ yang mewakili masing-masing perlakuan dan kontrol. Sebagai tambahan dilakukan pula pengukuran suhu dan kelembaban di lapangan, dan pengambilan data iklim lokasi penelitian di Badan Meteorologi Klimatologi dan Geofisika (BMKG) Stasiun Meteorologi Klas III Pomalaa Kolaka. Data yang diperoleh dianalisis secara statistik menggunakan SPSS (Stastistical Package for the Sosial Science) versi 16.0.

Sampel tanah lapangan yang diambil menggunakan ring sample ditimbang dan dicatat sebagai berat tanah basah. Kemudian, dikeringkan bersama ring sample ke dalam oven pada suhu $105^{\circ} \mathrm{C}$ hingga berat konstan. Setelah dingin, ring sample ditimbang sebagai berat kering tanah. Tanah pada ring dikeluarkan dan ring ditimbang sebagai berat ring kosong, ring juga diukur tinggi dan diameter untuk menghitung besarnya volume tanah. Menentukan kadar air tanah, bobot isi dan porositas tanah menggunakan rumus:

Kadar air tanah $=\frac{\text { berat basah-berat kering }}{\text { berat kering-berang ring kosong }} \times 100 \%$
Bobot isi tanah $=\frac{\left(\text { berat basah-berat ring kosong) } \frac{100}{(100+\text { kadar air tanah) }}\right.}{\text { Volume tanah }}$ 
Porositas tanah $=\frac{\text { bobot isi tanah }}{\text { berat jenis tanah }} \times 100 \%$

(Balai Penelitian Tanah, 2004).

Tahapan analisis tanah lainnya dilakukan di laboratorium Balai Penelitian Tanaman dan Sayuran (BPTS) di Lembang. Metode yang digunakan antara lain tekstur tanah (pipet), bahan organik (pembakaran/furnace), karbon (spektrofotometri), nitrogen (metode Kjehdahl), fosfor (spektrofotometri) dan kalium (flamefotometri).

\section{HASIL DAN PEMBAHASAN}

Pengaruh deltametrin terhadap fisik tanah dapat dilihat pada Gambar 1. Dapat dilihat bahwa porositas tanah (Gambar 1.A) pada perlakuan (25 ppm) lebih tinggi (37,80 \%) dibandingkan dengan porositas pada kontrol $(36,74 \%)$. Bobot isi tanah (Gambar 1.B) pada perlakuan $25 \mathrm{ppm}$ lebih rendah $\left(1,65 \mathrm{~g} / \mathrm{cm}^{3}\right)$ dibandingkan kontrol yang memiliki bobot isi tanah yang lebih tinggi $\left(1,68 \mathrm{~g} / \mathrm{cm}^{3}\right)$ meskipun perbedaan yang ada secara statistik tidak signifikan.
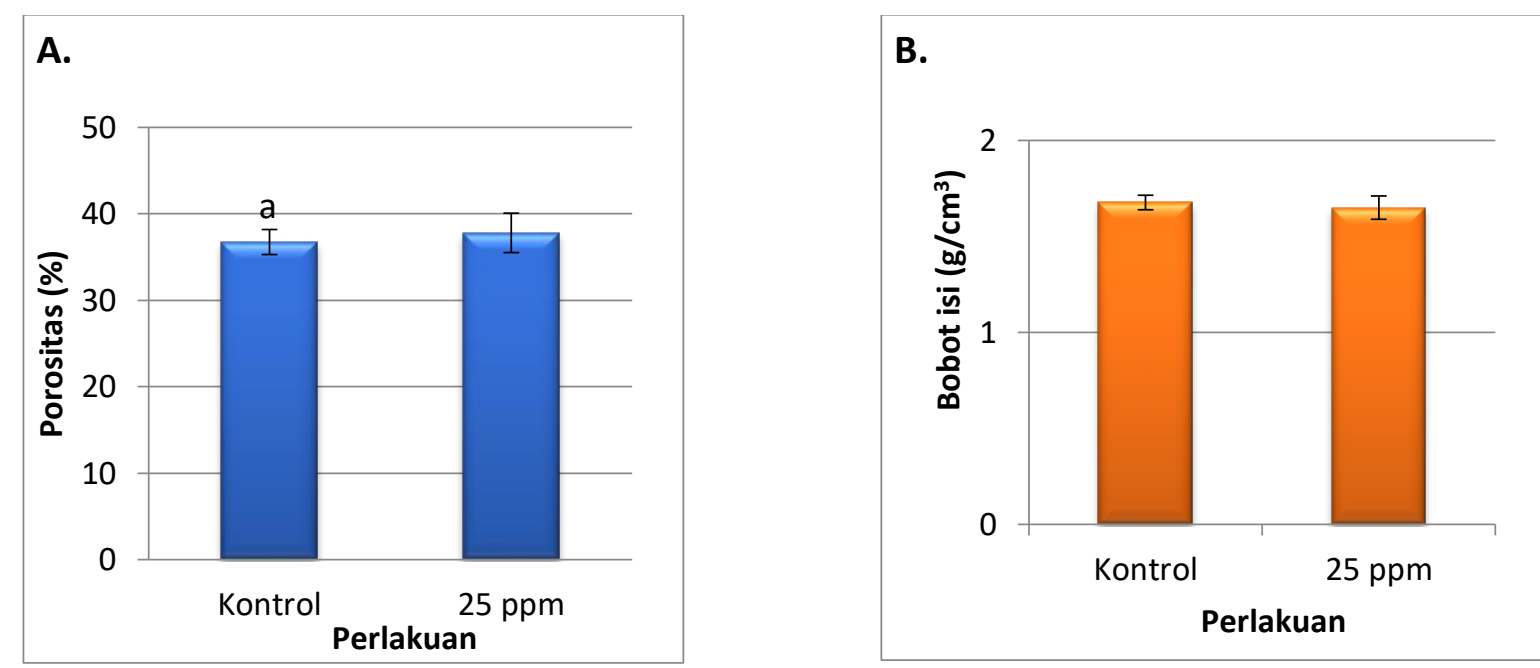

Gambar 1 Pengaruh deltametrin pada perlakuan kontrol dan 25 ppm terhadap fisik tanah (A) Porositas tanah (B) Bobot isi tanah. Data rata-rata mean $\pm \mathrm{SD}(\mathrm{P}<0,05)$.

Hasil penelitian ini diasumsikan bahwa pestisida deltametrin tidak memberi pengaruh terhadap porositas tanah. Diduga ada faktor lain yang berpengaruh terhadap porositas tanah yaitu karakteristik tanah pada lokasi penelitian. Dari data jenis tanah yang diperoleh di kabupaten Kolaka bahwa jenis tanah pada lokasi penelitian adalah jenis tanah Inceptisol, sehingga tidak ada perbedaan porositas tanah antara kontrol dan perlakuan karena memiliki karakteristik fisik yang cenderung sama. Faktor lain yang berpengaruh terhadap porositas tanah adalah aktifitas organisme tanah. Namun, pada penelitian ini faktor aktifitas organisme tanah tidak memberi pengaruh terhadap porositas. Hal ini tidak sejalan dengan pernyataan Johnherf, (2008) bahwa porositas tanah merupakan lubang-lubang tanah yang berisi oleh air dan udara, yang terbentuk akibat berbagai aktifitas didalamnya seperti fauna tanah dan perakaran tanaman. Selain aktifitas organisme dalam tanah, porositas tanah juga dipengaruhi oleh kepadatan tanah (bulk density), makin tinggi kepadatan tanah maka makin rendah persentase pori tanah (Haridjaja dkk., 2010).

Pada Gambar 1.B terlihat bahwa pada perlakuan $(25 \mathrm{ppm})$ memiliki bobot isi yang lebih rendah $(1,65$ $\left.\mathrm{g} / \mathrm{cm}^{3}\right)$ dibandingkan dengan kontrol $\left(1,68 \mathrm{~g} / \mathrm{cm}^{3}\right)$ namun perbedaan tersebut secara statistik tidak berbeda secara nyata. Pada pengamatan ini, deltametrin juga tidak memberi pengaruh terhadap bobot isi tanah. Diduga perbedaan antara bobot isi perlakuan dan kontrol karena perbedaan tekstur tanah. Di mana tekstur tanah pada perlakuan 25 ppm lebih banyak mengandung pasir (lempung berpasir) dibandingkan dengan tekstur tanah pada kontrol yang memiliki tekstur tanah dengan kandungan pasir lebih sedikit (lempung liat berpasir). Hal ini dapat diartikan bahwa tanah dengan kandungan pasir lebih tinggi memiliki porositas yang lebih tinggi dan bobot isi 
lebih rendah (Gambar 1.A) daripada tanah liat atau debu, dan dapat dikatakan bahwa perbedaan tekstur tanah secara tidak langsung mempengaruhi ukuran dan jumlah pori-pori tanah yang terbentuk serta bobot isi tanah. Sesuai dengan pernyataan dari Suripin, (2001) bahwa tekstur tanah berpengaruh terhadap jumlah porositas tanah dan bobot isi tanah.

Pengaruh deltametrin terhadap kelimpahan dan keragaman fauna tanah di perkebunan kakao dapat dilihat pada Gambar 2.A dan 2.B. Terlihat bahwa kelimpahan fauna tanah pada perlakuan $25 \mathrm{ppm}$ (Gambar 2.B) lebih rendah hanya mencapai 32 ekor dibandingkan kontrol (Gambar 2.A) yang mencapai 69 ekor, kelimpahan merupakan jumlah individu dalam satuan luas tertentu. Penurunan jumlah kelimpahan fauna tanah hingga 50\% disekitar pohon kakao tersebut diduga akibat aplikasi deltametrin. Hasil ini sesuai Bhanu dkk., 2011 bahwa aplikasi insektisida dapat menurunkan jumlah kelimpahan serangga. Penurunan kelimpahan serangga ini karena paparan deltametrin yang mengakibatkan terjadinya perubahan perilaku serangga dan terjadi kematian (mortalitas) (Meilin dan Praptana, 2014). Sebuah penelitian dari Meilin (2012); Meilin dan Praptana, (2014) bahwa aplikasi deltametrin memberi efek negatif pada imago parasitoid Anagrus nilaparvatae menyebabkan gangguan komunikasi seksual, perkembangan keturunan menjadi menurun, pencarian inang kurang aktif, umur pendek.
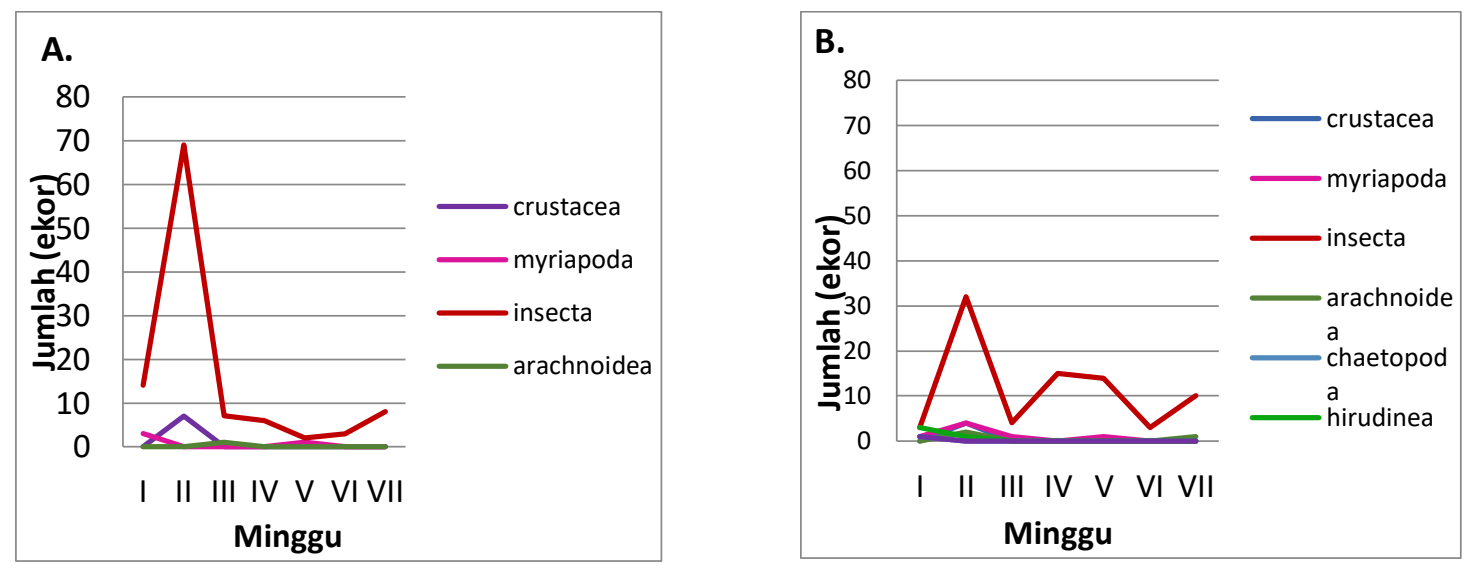

Gambar 2 Pengaruh deltametrin pada konsentrasi 25 ppm terhadap kelimpahan dan keragaman fauna tanah

Keragaman fauna tanah pada perlakuan 25 ppm lebih tinggi yaitu terdapat 7 kelas fauna tanah dibandingkan dengan kelimpahan fauna tanah pada kontrol yang hanya terdapat 4 kelas. Pada perlakuan 25 ppm tersebut terdapat Chaetopoda (cacing), Hirudinea (lintah), Gastropoda (siput/keong), Crustaecea (tomcat), Myrapoda (luwing, pillbug), Insecta (semut, jangkrik, kumbang) dan Arachnoidea(laba-laba). Pada kontrol yang hanya terdapat 4 kelas fauna tanah yaitu Crustaeceae (tomcat), Myrapoda (luwing, pillbug), Insecta (semut, jangkrik, kumbang) dan Arachnoidea(laba-laba). Hal ini dimungkinkan bahwa empat kelas fauna tanah pada perlakuan 25 ppm (Chaetopoda(cacing), Hirudinea(lintah), Gastropoda (siput/keong)) merupakan fauna-fauna tanah pendatang yang hanya lewat dan terperangkap dalam pitfall trap.

Dari hasil pengamatan kelimpahan dan keragaman fauna tanah ini (Gambar 2), dapat diasumsikan bahwa deltametrin menurunkan jumlah kelimpahan fauna tanah dan tidak memberi pengaruh terhadap keragaman fauna tanah. Namun deltametrin bukanlah satu-satunya yang menjadi faktor utama, faktor lingkungan lainnya juga menjadi faktor penting terhadap dinamika populasi fauna tanah, seperti $\mathrm{pH}$, kualitas sumberdaya makanan dan kondisi lingkungan. Pada penelitian ini menunjukan bahwa kelimpahan arthropoda menurun seiring dengan meningkatnya $\mathrm{pH}$ tanah, pada perlakuan $25 \mathrm{ppm} \mathrm{pH}$ tanah 6 dan pada kontrol pH tanah 5,8. Kilowasid dkk., (2013) menyatakan bahwa pola perubahan komunitas fauna tanah dapat dipengaruhi pula oleh faktor lingkungan yang berperan penting dalam penstrukturan komunitasnya seperti $\mathrm{pH}$ tanah, dari hasil yang diperoleh bahwa kelimpahan luwing berkorelasi negatif terhadap pH tanah. Namun, hasil penelitian Lavelle dkk., (1995) menunjukan kelimpahan arthropoda meningkat seiring meningkatnya pH tanah. Kualitas sumberdaya makanan dan kondisi lingkungan tanah juga sangat mempengaruhi komunitas fauna tanah 
(Hughes dkk., 1999) seperti kandungan lignin serasah (Adejuyigbe dkk. 1999) nitrogen dan bahan organik (Scheu, 2005). Namun pada penelitian ini tidak diamati kualitas sumberdaya makanan organisme (serasah).

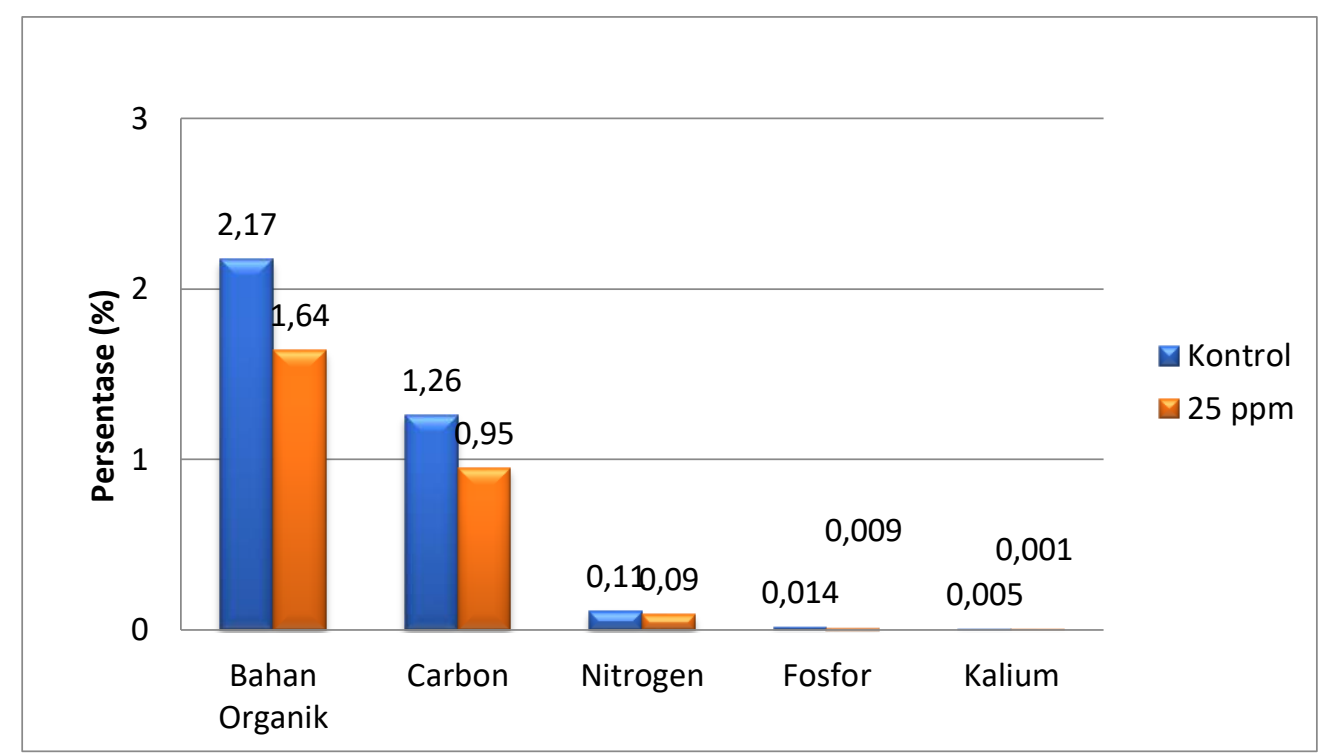

Gambar 3 Pengaruh deltametrin pada konsentrasi 25 ppm terhadap kandungan bahan organik tanah, karbon, nitrogen, fospor dan kalium.

Pada Gambar 3 terlihat kandungan bahan organik tanah pada perlakuan 25 ppm lebih rendah yaitu $1,64 \%$ dibandingkan dengan kontrol yaitu 2,17\%, hal ini dapat diasumsikan bahwa penggunaan deltametrin dapat menurunkan kandungan bahan organik tanah. Diduga deltametrin berpengaruh terhadap proses dekomposisi serasah oleh organisme tanah, yang pada akhirnya mempengaruhi kandungan bahan organik. Hasil pengamatan kelimpahan fauna tanah (Gambar 2) menunjukan bahwa kelimpahan fauna tanah pada perlakuan $25 \mathrm{ppm}$ lebih rendah dibanding dengan kelimpahan fauna tanah pada kontrol. Pengamatan tersebut diikuti dengan kandungan bahan organik pada perlakuan $25 \mathrm{ppm}$ lebih rendah pula dibandingkan dengan kandungan bahan organik kontrol. Rendahnya kelimpahan fauna tanah pada perlakuan 25 ppm diasumsikan menurunkan aktifitas dekomposisi serasah dan bahan organik tanah menjadi rendah meskipun pada penelitian ini tidak diamati proses dekomposisinya. Seperti pernyataan dari Grizelle and Timothy, (2001); Fitrahtunnisadan Ilhamdi (2013), bahwa Fauna tanah secara positif mempengaruhi laju pengomposan dan perpindahan bahan organik dan serasah yang berada pada daerah yang mempunyai jumlah mikroorganisme yang lebih banyak cenderung lebih cepat terdekomposisi dibanding pada daerah yang mempunyai jumlah mikroorganisme sedikit (Saetre 1998; Sulistiyantodkk., 2005).

Selain itu, jenis serasah pada penelitian ini terbatas karena penelitian ini dilakukan di kebun kakao yang sangat minim oleh jenis tanaman lainnya dan hanya didominasi oleh kakao. Pada lokasi penelitian, di lokasi perlakuan 25 ppm terdapat beberapa tanaman disekitar kakao dibandingkan dengan lokasi kontrol. Namun, hasil analisis bahan organik pada perlakuan lebih rendah. Ini tidak sesuai dengan beberapa literatur yang menyatakan bahwa semakin banyak jenis serasah maka pengurainnya lebih cepat dibandingkan dengan hanya satu jenis serasah. Pada penelitian Fitrahtunnisadan Ilhamdi (2013) diperoleh bahwa keanekaragaman fauna tanah yang berperan dalam proses pengomposan yang paling tinggi terdapat pada campuran beberapa jenis bahan serasah, sedangkan keanekaragaman paling rendah terdapat pada satu jenis bahan serasah. Hal ini lebih ditekankan pada pernyataan Suin 1997; Fitrahtunnisadan Ilhamdi. 2013 bahwa serasah tanaman sangat menentukan kepadatan fauna tanah, apabila bahan asalnya merupakan campuran dari berbagai macam bahan tanaman, maka proses penguraiannya relatif cepat daripada bahan-bahan yang berasal dari tanaman-tanaman sejenis, sehingga semakin beragam bahan organik maka penguraiannya semakin cepat.

Perbedaan kandungan karbon tanah pada perlakuan 25 ppm dan kontrol terlihat pada Gambar 3. Terlihat bahwa kandungan karbon pada perlakuan deltametrin 25 ppm lebih rendah yaitu 0,95\% dibandingkan dengan 
kandungan karbon pada kontrol yaitu 1,26\%. Kandungan karbon tanah ini diduga dipengaruhi oleh kandungan bahan organik, semakin tinggi bahan organik maka kandungan karbon semakin tinggi, dan sebaliknya semakin rendah bahan organik maka kandungan karbon semakin rendah pula. Powlson dkk., 1987; Wardle, 1992; Vance dan Chapin, 2001; Ekblad dan Nordgren, 2002; Tu dkk. 2006 bahwa peningkatan jumlah bahan organik akan cenderung meningkatkan jumlah Karbon organik dan ketersediaan energy bagi mikroba tanah dan dapat meningkatkan biomassa mikroba tanah serta mengurangi jumlah karbon tanah. Hairiah et al., 2001 menambahkan bahwa jumlah karbon tanah dipengaruhi oleh proses dekomposisi serasah, semakin tinggi proses dekomposisi maka semakin tinggi karbon yang digunakan sehingga kandungan karbon di tanah menjadi rendah. Benbi and Richter (2002) juga menyatakan bahwa Dalamproses dekomposisi, mikroorganismememanfaatkan senyawa karbon dalam bahanorganik untuk memperoleh energi dengan hasilsampingan berupa $\mathrm{CO} 2$. Hal ini yangmenyebabkan selama dekomposisi, kadar Cbahan organik akan berkurang sehingga nisbah $\mathrm{C} / \mathrm{N}$ semakin rendah.

Selain itu, rendahnya kandungan karbon tanah pada perlakuan diasumsikan dipengaruhi oleh bobot isi tanah. Pada perlakuan $25 \mathrm{ppm}$ memiliki bobot isi tanah lebih rendah $\left(1,65 \mathrm{~g} / \mathrm{cm}^{3}\right)$ dibandingkan dengan kontrol $\left(1,68 \mathrm{~g} / \mathrm{cm}^{3}\right)$ meskipun secara statistik tidak berbeda secara nyata. Dari data bobot isi tersebut berhubungan dengan kandungan karbon tanah, bobot isi tanah yang rendah pada perlakuan 25 ppm juga memiliki karbon yang rendah, sebaliknya bobot isi tanah yang tinggi pada kontrol juga memiliki karbon yang tinggi pula. Hal ini sejalan dengan pernyataan dari Fetriza (2011) bahwa bobot isi tanah yang rendah akan menyebabkan semakin menurunnya penyimpanan cadangan karbon didalam tanah. Sebaliknya, semakin tinggi bobot isi tanah maka cadangan karbon akan semakin meningkat.

Perbedaan kandungan nitrogen tanah pada perlakuan $25 \mathrm{ppm}$ dan kontrol dapat dilihat pada tabel 3.3. Pada perlakuan 25 ppm memiliki kandungan nitrogen 0,09\% dan pada kontrol memiliki kandungan nitrogen $0,11 \%$. Perbedaan kandungan nitrogen tanah ini diduga dipengaruhi oleh bahan organik. Seperti halnya karbon tanah, nitrogen juga berkorelasi terhadap kandunganbahan organik, bahan organik tanah pada perlakuan 25 ppm lebih rendah dibandingkan dengan bahan organik kontrol, begitupula kandungan nitrogen tanah pada perlakuan lebih rendah dibandingkan dengan kontrol. Sesuai dengan pernyataan dari Cookson dkk., 2005 bahwa kemampuan tanah dalam menyediakan nitrogen sangat ditentukan oleh kondisi dan jumlah bahan organik tanah dan Fließbach dkk (2007) menyatakan bahwa bahan organic yang tinggi akan meningkatkan nitrogen dan karbon tanah.

Selain itu, beberapa literatur mengatakan bahwa jenis tumbuhan kakao merupakan tumbuhan yang tumbuh lambat dan laju pendauran nitrogen menjadi lambat. Seperti pernyataan Bardgett dan Wardle. 2010; Kilowasid, 2013 bahwa karakteristik tumbuhan sangat berkontribusi terhadap kualitas detritus yang masuk ke dalam bahan organik tanah dan tipe tumbuhan yang tumbuh lambat memiliki serasah yang mengandung senyawa lignin dan polifenol tinggi yang dapat menghambat pendauran nitrogen dibandingkan pada tanaman yang tumbuh cepat.

Pengaruh deltametrin terhadap kandungan fosfor tanah pada perlakuan $25 \mathrm{ppm}$ dan kontrol terlihat pada Gambar 3. Pada penelitian ini, jumlah forfor tanah sangat rendah, pada perlakuan 25 ppm kandungan fosfor $0,009 \%$ dan kontrol terdapat $0,14 \%$. Rendahnya jumlah fosfor ini diduga terjadi penurunan proses mineralisasi oleh organisme tanah dan secara tidak langsung akan membantu pelepasan $\mathrm{P}$ yang terfiksasi, ini juga dipengaruhi oleh kandungan bahan organik, terlihat pada jumlah bahan organik pada perlakuan 25 ppm lebih rendah dibanding kontrol. Seperti pada penelitian Minardi dkk., (2011) tentang pengaruh pemberian bahan organik terhadap serapan fosfor, dari hasil yang diperoleh bahwa bahan organik berpengaruh nyata terhadap ketersediaan $\mathrm{P}$ dalam tanah baik melalui proses mineralisasi maupun secara tidak langsung membantu dalam pelepasan P yang terfiksasi (Suntoro, 2003; Minardi dkk., 2011).

Perbedaan kandungan kalium pada perlakuan 25 ppm dan kontrol terlihat pada Gambar 3. Seperti halnya jumlah fosfor, jumlah kalium tanah pada penelitian ini memang sangat rendah, pada perlakuan 25 ppm hanya terdapat $0,001 \%$ dan pada kontrol terdapat $0,005 \%$. Hal ini dapat diasumsikan bahwa kalium merupakan unsur yang mudah hilang akibat pencucian, digunakan tanaman maupun tidak mudah terikat oleh tanaman, (Rogers, 2002 dan Chuyong dkk., 2002).

Seperti pada penelitian Sulistiyanto dkk. (2005) pada pengukuran laju dekomposisi dan pelepasan hara serasah pada dua sub tipe hutan rawa gambut di Kalimantan Tengah, hasil yang diperoleh pada 6 bulan pertama $\mathrm{K}$ yang tertinggal 39,3\% dari serasah MSF (mixed swamp forest)dan 8,9\% dari serasah asal LPF (low pole 
https://jurnal.unsulbar.ac.id/index.php/saintifik

forest) dan diasumsikan bahwa kalium adalah hara yang paling cepat hilang karena bersifat mobile baik di tanaman maupun di tanah dan mudah tercuci, Rogers (2002) dan Chuyong dkk. (2002). Selain itu, Marshner, 1985; Ribeiro dkk.2002; Sulistiyanto dkk. 2005 menambahkan bahwa rendahnya hara kalium merupakan konsekuensi dari sifat mobilnya dan tidak terikat kuat pada struktur sel tanaman.

\section{KESIMPULAN}

Dari uraian diatas dapat disimpulkan bahwa deltametrin tidak berpengaruh terhadap fisik tanah, namun berpengaruh terhadap biologi tanah dan kimia tanah.

\section{DAFTAR PUSTAKA}

Bhanu.S., Archana.S., Ajay.K., Bhatt.J.L Bajpai.S.P., Singh.S., Vandana.B., 2011. Impact of Deltametrhin on Environment, Use as an Insecticide and its Bacterial Degradation-A Preliminary Study. International Journal Of enviromental science Vol.1 No 5, 2011.

Haridjaja.O., Hidayat.Y., Maryamah.L.S., 2010. Pengaruh Bobot Isi Tanah Terhadap Sifat Fisik Tanah Dan Perkecambahan Benih Kacang Tanah Dan Kedelai. Jurnal Ilmu Pertanian Indonesia. Desember 2010. Hlm. 147-152. ISSN 0853-4217.

Hartati., 2012. Prediksi Kelarutan Theobromine Pada Berbagai Pelarut Menggunakan Parameter Kelarutan Hildebrand. Journal Momentum, Vol.8, no 1, april 2012:11-16

Meilin.A dan Praptana.R.H. 2014. Dampak Insektisida Deltametrin Konsentrasi Subletal pada Perilaku dan Biologi Parasitoid. Jurnal Iptek Tanaman Pangan Vol 9 No.2 2014.

Minardi.S., Syamsiyah.J., Sukoco., 2011. Pengaruh Bahan Organik Dan Pupuk Fosfor Terhadap Ketersediaan Dan Serapan Fosfor Pada Andisols Dengan Indikator Tanaman Jagung Manis (Zea mays saccharata strurt). Jurnal Ilmu Tanah dan Agroklimatologi 8(1) 2011.

Sulistiyanto.y., Rilay.J.O., Limin.S.H. 2005. Laju Dekomposisi dan pelepasan Hara dari Serasah Pada Dua Sub-Tipr Hutan Rawa Gambut Di Kalimantan Tengah. Jurnal Manajemen Hutan tropika Vol.XI No.2 : 114 (2005).

Syafira.G., Permatasari.R., Wardani.N., 2012. Theobromine Effect on Enamel Surface Microhardness: In Vitro. Journal Of Dentistry Indonesia 2012, Vol.19.No.2, 32-36.

Wahyudi.T., Pangabean dan Pujianto. 2008. Panduan Lengkap Kakao. Penebar swadaya. Jakarta. 